\title{
CHRONICLE
}


Ko Swan Sik - 9789047406211

Downloaded from Brill.com04/26/2023 01:29:51PM via free access 


\section{CHRONICLE OF EVENTS AND INCIDENTS RELATING TO ASIA WITH RELEVANCE TO INTERNATIONAL LAW}

July 1999 - June 2000

\section{Ko Swan Sik}

\section{TABLE OF HEADINGS}

Arms sales and supplies

Asia-Pacific Economic Cooperation forum

(APEC)

Association of South East Asian Nations (ASEAN)

Borders, border disputes and border incidents

Colonies

Diplomatic and consular immunity

Diplomatic and consular relations

Divided states: China

Divided states: Korea

Insurgents

International Court of Justice

International crimes and their adjudication

International economic and trade relations

Inter-state relations: general aspects

(Non-)Intervention

Japan's military role

Maritime delimitaion
Migrant workers

Military alliance

Military cooperation

Missile technology

Monetary matters

Nationality

Nuclear energy matters

Organization of the Islamic Conference

Piracy

Refugees

Regional security

Sanctions

Self-defence

Self-determination

Settlement of disputes

Special territories within a state: Kashmir

State succession

Territorial claims and disputes

Terrorism

Weapons

\footnotetext{
* General Editor. For the considerations underlying the Chronicle, see the "Editorial Introduction" in 1 AsianYIL (1991) 265.
}

Asian Yearbook of International Law, Volume 9 (B.S. Chimni et al., eds.)

(C) 2004 Koninklijke Brill NV. Printed in The Netherlands, pp. 385-420. 
ARMS SALES AND SUPPLIES

See: Divided states: China

\section{ASIA-PACIFIC ECONOMIC COOPERATION FORUM (APEC)}

APEC held its annual meeting at Auckland, New Zealand, starting 9 September 1999. The trade ministers agreed to take a stand against farm-export subsidies (aimed at the EU), but on little else, except items such as duties on electronic commerce and government procurement. They did, however, endorse a position advocated by Japan, calling for the next round of WTO global trade talks to be "structured so that the outcomes are finalized, bound and fully implemented as a single package". This was contrary to the preference of the US which called for negotiations on a sector-bysector basis. (IHT 09-09, 10-09, 11/12-09-99)

\section{ASSOCIATION OF SOUTHEAST ASIAN NATIONS (ASEAN)}

(See also: Territorial claims and disputes)

\section{“Flexible engagement" approach}

The notion of "flexible engagement" referred to by the Thai foreign minister in July 1998 (see 8 Asian YIL 257) was further specified in a Thai "non-paper" of the same month, as (a) a continued commitment to the establishment of an ASEAN regional community; (b) a continued commitment to non-interference as the cardinal principle for the conduct of relations; (c) responsibilities for contributing to the achievement of common regional goals and for managing bilateral differences and improving bilateral relations, and rights to preserve one's own identity and to espouse or articulate one's own beliefs and values; (d) a commitment to non-interference that must be subjected to reality tests and must, accordingly, be flexible, because as the region becomes more interdependent, the dividing line between domestic affairs and external or transnational issues is less clear. Many "domestic" affairs have obvious external or transnational dimensions, adversely affecting neighbours, the region and the region's relations with others. In such cases, the affected countries should be able to express their opinions and concerns in an open, frank and constructive manner, which is not, and should not be, considered "interference" in the domestic affairs of fellow member-states. (Courtesy K. Kittichaisaree)

\section{Annual foreign ministers meeting}

The annual meeting was held at Singapore on 23-24 July 1999. (IHT 24/25-07-99)

\section{East Asian attempts to increased integration}

The Third Informal ASEAN Summit Meeting took place on 27-28 November 1999. There were reports about moves to bring South-east and North-east Asia closer together, based on a plan to enlarge the proposed ASEAN Free Trade Area to include 
China, Japan, South Korea and eventually other North-east Asian countries. (IHT 26-11-99) (see infra, at 398)

\section{BORDERS, BORDER DISPUTES AND BORDER INCIDENTS \\ (See also: State succession)}

\section{Bangladesh - India}

The two countries exchanged fire during three days in August 1999 over a piece of disputed land 210 kilometres southeast of Dhaka. The gun battle ended after talks were conducted between the two sides on a telephone hot line.

The battle began when farmers from the two sides clashed over a disputed shoal on the Muhuri River along the border. Some Indian farmers reportedly intruded into an area and began fencing it, and Bangladeshi farmers tried to push them back.

The disputed 120-acre shoal had been claimed by both countries since the 1960s. Bangladesh and India share a 2,700-mile frontier, and in the last two decades their security forces had traded fire 29 times in border disputes. (IHT 24-08, 26-08-99)

\section{East Timor - Indonesia}

Troops of the multinational force in East Timor (see: Self-determination) and Indonesian troops became involved in a shooting incident on 10 October 1999 in the border area between East and West Timor near the town of Motaain which straddles the border. The fighting was apparently triggered by confusion over the exact location of the border, and by the use of different maps. The Indonesians were reported to have used a map based on an old, Dutch, chart, showing Motaain in West Timor. A newer, Indonesian-drawn, map used by the Australians located the town in East Timor. (IHT 11-10-99)

\section{Laos - Thailand}

Boundary disputes began to materialize as early as in 1893 when Laos was still under French rule. In 1984 Laos and Thailand concluded an agreement to settle the disputes, but the efforts in several cases failed to achieve real results.

In 1996 a Thai-Lao Joint Commission agreed to demarcate the 1,100-kilometrelong land boundary. Another 710 kilometres of the boundary is in the Mekong River. By 19 July 1998 the Commission had surveyed 538 kilometres of the boundary and placed boundary pillars along 259 kilometres of land boundary in the northern provinces of Chiang Rai, Phayao and Nan, bordering Laos. (Courtesy K.Kittichaisaree)

\section{Myanmar - Thailand}

Among the boundary issues between the two countries is the disputed boundary at Doi Lang in the Mae Ai District of (the Thai) Chiang Mai Province, Hill 491 in the Tha Sae District of (the Thai) Chumphon Province, as well as the sovereignty over Nok, Lam and Khan islets in the Andaman Sea. (Courtesy K.Kittichaisaree) 


\section{North - South Korea maritime boundary \\ (See also infra at 392)}

The following summary is made on the basis of an account given by experts in maritime policy of the East-West Center at Honolulu:

The "Northern Limit Line" (NLL), a demarcation line delimiting South Korean and North Korean jurisdiction on the sea west of the Korean peninsula (see also 8 Asian YIL 265) was unilaterally drawn by the UN Command, equidistant between five islands occupied by South Korea and the North Korean coastline. The US and South Korea held the view that both Koreas must respect the line until a new agreement could be reached. North Korea did not succeed in obtaining a new negotiated boundary line..

Since the NLL veers sharply to the north after leaving land, North Korea claimed that it unfairly allots some of its waters to South Korea. North Korea further argued that its vessels had regularly fished in the waters claimed by South Korea, and that since the 1970s it had claimed, under customary international law, a 12-nautical mile territorial sea in the area which extends well south of the NLL. North Korean fishing boats and naval vessels had crossed the NLL several dozen times a year since the late 1970s.

The immediate cause of the June 1999 confrontation (see 8 Asian YIL 264) was the concentration of valuable crabs south of the NLL, in an area where South Korea used to allow South Korean fishing only in the month of June.

From other US sources a following data can be derived: The Korean armistice agreement of 1953 never specifically addressed the contiguous waters between North and South Korea. At the time it was assumed that the boundary established at the cessation of hostilities, the 38th parallel, would extend outward into the sea. This, however, did not apply to the west coast, because of the meandering coastline and the countless islands in the area. The only true boundaries established there were perimeters around each of the UN-controlled and still-disputed north-west islands. A security boundary of three nautical miles was established around each of the UNoccupied islands. These boundaries were recognized though often violated by North Korea. The NLL, however, was set by South Korea in order for its naval ships and patrol boats to conduct routine operations. (IHT 17-12, 29-12-99)

\section{COLONIES}

\section{Reversion of Macau to Chinese rule}

At midnight of 19 December 1999 the territory of Macau reverted to Chinese rule after being a Portuguese colony for 442 years. It was the last European colony in Asia. (IHT 20-12-99)

\section{DIPLOMATIC AND CONSULAR IMMUNITY}

See: Sanctions (For text of Sino-Portuguese Joint Declaration, see 5 Asian YIL (1995) 567 et seq.) 


\section{DIPLOMATIC AND CONSULAR RELATIONS}

(See also: Divided states: China)

\section{Unofficial papal representative}

It was reported that the Vatican was keeping an unofficial envoy in Hong Kong. The bishop was technically stationed at Manila but was in fact working as the papal representative in Hong Kong. The Vatican confirmed his presence in the region but said he was not on a diplomatic mission. (IHT 13-08-99)

\section{Denial of consular communication with detainee}

The British embassy was denied access to a UK national who was sentenced in a Myanmar court to 17 years' imprisonment. Myanmar is not a party to the 1963 Vienna Convention on Consular Relations [and is consequently not bound by its Article 36]. (IHT 08-09-99)

\section{North Korea}

Italy became the first of the Group of Seven leading industrialized countries (and the sixth EU member, after Austria, Denmark, Finland, Portugal and Sweden) to establish diplomatic relations with North Korea, on 4 January 2000. Germany and North Korea, had no full diplomatic relations, but North Korean officials still worked out of their former embassy building in (East) Berlin. Japan had started preparatory talks aimed at eventually normalizing relations (see infra, at 401) (IHT 05-01-00)

In April 1999 North Korea expressed its wish to have closer contacts with Australia with which it had had no official relations for the previous twenty-five years. After several talks the two countries decided in May 2000 to establish diplomatic relations. (IHT 12-06-00)

\section{DIVIDED STATES: CHINA}

(For reasons of technological inadequacy a number of data relating to the period 19971999 were not included in Vol.8 and have now been included in the current Volume.)

\section{Taiwanese attitudes}

Speaking as chairman of the ruling Nationalist Party the Taiwanese vice-president in August 1997 called for development of a new era where "Chinese people no longer fight Chinese people" and "Chinese people help Chinese people". He emphasized that his government supported reunification with the mainland and would not seek independence. He recalled that Taiwan had instituted a set of guidelines for unification under "reasonable, peaceful, equal and mutually beneficial" conditions. However, he urged the Chinese government to acknowledge that Taiwan was ruled by its own government and that the island could not possibly accept the "one country two systems" formula. (JP 26-08-97)

Accordingly the new Taiwanese premier in his address to parliament called on China to acknowledge the "split" across the Taiwan Strait and thus to stop insisting that it had sovereign powers over Taiwan. (JP 10-09-97) 


\section{Guidelines for National Unification}

The chairman of the (Taiwan) Mainland Affairs Council called on both sides to move to the second phase of the [above-mentioned] Guidelines for National Unification, which constituted a blueprint consisting of three stages: In the first stage Beijing needed to recognize Taiwan as a political entity instead of as a province of China, and renounce the use of force against the island. In the second phase, Taiwan would allow official visits as well as direct postal, commercial and transportation links across the Taiwan Strait. The third phase is to form a body to discuss the structure of a unified China. (JP 01-11-97)

\section{Taiwan-Papua New Guinea diplomatic relations}

Papua New Guinea recognized the government at Taiwan and both issued a communique on the establishment of diplomatic relations. China reacted by demanding from PNG that these relations be severed. (IHT 07-07-99) On 14 July 1999 a new prime minister was elected in PNG who announced he would review the decision. (IHT 15-07-99) The recognition accordingly reverted to Beijing sixteen days later. (IHT 22-07-99)

\section{"State-to-state" relations}

The Taiwanese president said in a radio interview on 10 July 1999 that bilateral talks between the island and the mainland could continue only if they were considered "state-to-state" rather than between "political entities": "Since we conducted our constitutional reforms in 1991, we have redefined cross-strait relations as nation-tonation, or at least as special state-to-state relations."

This was toned down when he stressed on 14 July 1999 that the Taiwanese mainland policy had remained intact. (IHT 15-07-99) Under intense pressure from the US and the Chinese government Taiwan announced it had decided to stop using several expressions such as "two Chinas", "one China two states" and "one nation, two countries", but it would continue to use the formulation "special state-to-state" relations. It was said that this amounts to a restatement of demands issued in 1998, namely, that Taiwan must be treated as Beijing's equal in political talks and that China must begin to democratize in order for reunification to occur. [The governing Nationalist Party in late August 1999 adopted the president's view and included the re-classification of the Sino-Taiwanese relations in one of its resolutions.]

One day later, the Taiwanese president once again reaffirmed his tough position, and the next month he said that Taiwan sought to take part in the regional missiledefence shield being considered by the US. Responding to this idea the Chinese side warned that the inclusion of Taiwan under a US missile shield would be an infringement of Chinese sovereignty. (see infra, at 400) (IHT 22-07, 23-07, 19-08, 30-08-99)

\section{US attitude}

(see also Inter-state relations: China - US)

The US State Department stated on 15 July 1999: "We would determine and consider any effort to determine the future of Taiwan by other than peaceful means as a threat to the peace and security of the Western Pacific area and of grave concern 
to the US." (IHT 17/18-07-99) On the other hand the US president emphasized to the Chinese president over the telephone that the US supported the one-China policy and had been encouraging Taiwan to do the same. (IHT 21-07-99) At the same time it was reported that the US Defense Department had decided to go ahead with the sale of advanced weapons and military equipment to Taiwan. (IHT 03-08-99)

It was reported that some doubt existed about military readiness and public morale in Taiwan to confront Chinese pressures. Concerned about Taiwan's defence capacity, the US Defense Department began a program in 1997 under which a steady stream of advisers had travelled to Taiwan to assess military weaknesses, particularly in the light of technological advances. (IHT 28-07-99)

For the first time in seven years the US in September 1999 took a position opposing the insertion of the issue of UN membership for Taiwan into the UN General Assembly agenda, thus making clear its unchanged "one China" policy. [The UNGA Steering Committee decided without a vote not to include the item on the agenda.] (IHT 17-09-99)

China and Taiwan for the first time asked the US to intervene and play a helpful role in helping China and Taiwan improve relations. Taiwan expressed its wish on 12 May 2000 and Chinese officials were reported to have made a similar request. On the other hand, the US since 1982 had vowed not to mediate between the two sides because of a belief that there was no immediate solution to the problem and because of fear that failed mediation could ruin US relations with either side. (IHT 13/14-05-00)

\section{New Chinese white paper and its aftermath}

Just a month before Taiwanese presidential elections China issued a white paper on 21 February 2000 in which China threatened to attack Taiwan if its leaders indefinitely delayed negotiations on reunification. The white paper also said that China would be justified in attacking Taiwan if the US continued arms sales or if Taiwan abandoned the "one China" theory. Previously such a threat applied only in the event that Taiwan declared independence or if it were occupied by a foreign power. However, the white paper appeared to accept that Taiwan should be treated as an equal of the mainland instead of as a "local government".

The ultimatum was obviously timed to influence the outcome of Taiwan's presidential elections. (IHT 22-02-00)

The US sharply rejected the Chinese threat the next day, viewing it "with great concern" (IHT 23-02-00) and Taiwan started pressing the US to sell it some very advanced defensive weapons, including four elaborately equipped warships. Under the 1979 Taiwan Relations Act the US government is to provide Taiwan with defensive weapons "in such quantity as may be necessary to enable Taiwan to maintain a sufficient self-defense capability". (IHT 02-03-00) On 17 April 2000 the US decided not to proceed with the sale of the advanced destroyers, although it did agree to sell Taiwan upgraded versions of three missiles and a long-range radar system. The Chinese foreign ministry reiterated its demand that the US stop all arms transfers to Taiwan "so as not to obstruct the improvement of China-US relations". (IHT 19-0400) 


\section{New mutual offers}

The newly elected president in Taiwan on 21 May 2000 announced his willingness to consider opening direct trade and transportation links with the mainland. He called the ban on direct postal, trade and transportation links ("Three links policy") "outdated, rigid and inflexible". Under this policy most Taiwan-mainland trade and investment passed through Hong Kong. (IHT 22-05-00)

On 28 June 2000 the new Taiwan president said that he accepted the "one China" principle and would thereby accept a 1992 formulation that both China and Taiwan could have their own definitions of what "one China" means. (IHT 29-06-00) However, the following day already the Chinese foreign ministry assailed the shift as disingenuous, emphasizing that Taiwan must endorse the mailand's claim that "'one China' means there is but one China, of which Taiwan is a part". (IHT 30-06-00)

\section{DIVIDED STATES: KOREA}

\section{Suspension of talks}

Inter-Korean talks which had started on 22 June 1999 at Beijing were suspended on 2 July 1999 because North Korea refused to discuss the issue of reuniting divided families, while South Korea made this a condition for the continuation of the promised aid of 200,000 tons of fertilizer, and also refused to apologize for the sinking of a Northern vessel on 15 June 1999 (see 8 Asian YIL 265) (IHT 3/4 -07-99)

\section{Four-party talks}

The sixth round of the four-party talks between North Korea, South Korea, China and the US (see 8 Asian YIL 262) started on 5 August 1999. (IHT 06-08-99)

\section{North Korean-UN Command talks on sea border}

(See also supra, at 388)

The talks following the naval incidents in June 1999 (see 8 Asian YIL 265) were resumed for the sixth time on 17 August 1999. North Korea disputed the sea border (the "Northern Limit Line") as claimed by the US-led UN Command and proposed talks with only the US military. It rejected South Korea as a dialogue partner on the issue, while the UN Command held the opinion that the two Koreas should settle the matter within the South-North Joint Military Committee established under Article 12 of the 1991 Reconciliation Agreement between North and South Korea (see 2 Asian YIL 410). (IHT 18-08, 01-09-99)

On 2 September 1999 North Korea announced that its military would consider its territorial waters as starting about 65 kilometres south of the line set by the UN Command in 1953. (IHT 03-09-99) 


\section{Use of cancer-causing defoliant}

In response to a furore that arose in South Korea the US recently confirmed that spraying of the cancer-causing defoliant "Agent Orange" had occurred in the late 1960s to clear the demilitarized zone between the two Koreas. There were differences over which country originated the proposal to use this method. (IHT 18-11-99)

\section{North-South Summit Meeting}

The new president of South Korea had dropped hostilities and had announced pursuing a policy of engagement, popularly known as the "sunshine policy". As part of it he encouraged South Korean business to start business in North Korea. He also lifted South Korean insistence on taking part in negotiations between the US and North Korea.

As a result it was announced on 10 April 2000 that secret negotiations had led to a North-South agreement for a summit meeting, with the South Korean president to visit North Korea in June 2000. It was to be the second such visit, the first being in 1948, after the division of the peninsula but before the creation of the separate states.

[The 1948 meeting, aimed at general elections in the whole country and a NorthSouth coalition government, was without success. Consequently, separate elections were held in South Korea.]

In preparing the meeting the parties agreed on merely a vague agenda, referring to the "three principles" contained in the North-South joint communique on national unity of 4 July 1972. Under these principles the parties would discuss "ways of realizing national reconciliation, peace and reunification". The three-day visit started on 13 June 2000. (IHT 11-04, 19-05, 13-06-00)

The meeting resulted in an agreement that was signed on 14 June 2000 and that contained a multipoint-program of national reconciliation. It was more a general statement of common principles than a detailed proposal. It included reconciliation and unification; establishment of peace; exchange visits of members of separated families, and increased cultural exchanges. It was also agreed that the North Korean leader would visit Seoul "at the earliest appropriate moment". (IHT 15-06-00)

\section{INSURGENTS}

\section{Indonesian Province of Aceh}

In the course of the past decades an insurgent movement had been active in the north-western Indonesian province of Aceh in the northern tip of the Island of Sumatra. The territory is strategically placed on the Strait of Malacca shipping lane, is rich in oil and natural gas deposits, and is staunchly Muslim. Aceh has a long history of resisting central authority, dating from Dutch colonial rule. It was an independent sultanate when Dutch colonial forces occupied it in the early twentieth century after a 30-year struggle. It played an important role in the establishment of the Indonesian republic in 1945 and in 1961 Aceh was designated a special territory with autonomy in religion, culture and education. Since the 1970s the insurgents were 
organized in the so-called Free Aceh Movement (Gerakan Aceh Merdeka, GAM) which declared Acehnese independence on 4 December 1976. Because of its historically determined features the province was promised the status of a special autonomous region since the country had achieved independence, but this was never followed through.

The conflict worsened from the late 1980s, when the rebels began to attack the military and non-Acehnese migrants to the region. The army responded with indiscriminate force, and in the period from 1989 till 1998 Aceh was declared a "military operations area". The spiral of insurgency and repression had claimed numerous victims in terms of lives as well as other factors.

Prospects for negotiations to end the fighting were not hopeful. The rebels said that the government had first to withdraw its troops, whereupon the army said the rebels should stop their campaign of violence before talks could begin. (IHT 17-08, 19-08, 23-08-99)

On 8 November 1999 hundreds of thousands of residents of the province joined in the largest independence protest in Indonesian history, demanding a referendum, which was rejected by the government. Many people, among whom the armed forces, were said to fear that granting a referendum to Aceh could lead to the break-up of Indonesia. (IHT 09-11, 10-11-99) Nevertheless, the Indonesian president announced on 16 November 1999 that Aceh could hold its referendum seven months hence, but only to choose between the status quo and greater autonomy; the latter choice would grant the provincial government the right to its own laws based on Islamic teachings and to retain a major part of the revenues originating from the region. (IHT 17-11-99)

It was reported in early May 2000 that the Indonesian government and the rebels would sign a memorandum of understanding, containing an agreement not to continue the violence and start negotiations to resolve the conflict. The agreement was the result of several meetings at Geneva with the assistance of the (Swiss) Henri Dunant Center for Humanitarian Dialogue as 'facilitator'. (IHT 05-05-00) The "humanitarian pause" agreement was signed on 12 May (IHT 02-06-00) but although the cease-fire went into effect on 2 June it had not brought about significant improvement in the security situation. (IHT 14-06-00)

\section{Indonesian province of Irian Jaya}

A “people's congress" held in early June 2000 in this furthest-eastern Indonesian province closed with a resolution "affirming sovereignty". It made no formal declaration of independence, nor did it set up a government; it thus avoided a crackdown by the Indonesian government. Instead the resolution called for a dialogue on autonomy with the government. (IHT 05-06-00) However, a few days after the event fighting broke out between pro-Indonesian and pro-independence militias.

Responding to the sovereignty declaration the Indonesian president approved the appointment of four new local deputy governors for the province, allowed the Irianese flag to fly alongside the Indonesian flag, and set up a commission to investigate charges of human rights abuses. (IHT 19-06-00) 


\section{Philippine Communists}

The peace talks between the government and the Communist rebels broke down because, as the government peace negotiating panel said, the rebels' demands undermined the country's political and constitutional sovereignty. (IHT 13-07-99)

\section{Islamic insurgents in the Philippines}

In the context of peace negotiations that had started in1999 the Philippine government threatened the insurgents of the Moro Islamic Liberation Front (MILF) with all-out war if they failed to sign a peace agreement by 30 June 2000. As a result the Front, whose aim it was to turn large portions of Mindanao Island into a separate Muslim country, walked out of the talks and embarked on a spate of activities causing terror at Mindanao in early May 2000, setting off bombs, firing grenades at an airport and taking hostages. A last session of the talks took place on 1 June and the latter were scheduled to be resumed later that month but the Front preferred to postpone them indefinitely.

A similarly forceful stance was taken by the government with members of another Islamic separatist organization, Abu Sayyaf, who on 23 April 2000 had abducted persons from the nearby Malaysian diving resort island of Sipadan, and held them hostage on (Philippine) Jolo Island.

The insurgents demanded a return to barter trading in the southern Philippines, a ban on large (mostly foreign-owned) fishing boats from traditional fishing grounds, the full implementation of a 1976 agreement that called for a thirteen-province autonomous Muslim region, and the formation of a commission to examine the problems of Filipino Muslims living in neighbouring Malaysia. However, in early June 2000 the MILF agreed to consider a government-proposed political settlement involving autonomy. (IHT 05-05, 06/07-05, 02-06, 13-06, 20-06-00)

\section{Tamil rebellion in Sri Lanka}

It was reported in early May 2000 that the Tamil Tiger rebels ("Liberation Tigers of Tamil Eelam") had made significant advances in their offensive to recapture the city of Jaffna, the cultural capital of the Hindu Tamil-dominated part of the country, which they controlled between 1990 and 1995 (see 6 Asian YIL 391; see also 5 Asian YIL 424). Confronted with this threat the country was under the Public Security Act put on war status, for the first time in Sri Lanka's 51 years of independence, from its previous emergency rule.

India ruled out Indian arms assistance to the Sri Lankan government but offered food and medicine if needed (IHT 05-05-00), while hosting Norwegian efforts to broker a peace agreement. (IHT 12-05-00) An Indian offer to mediate, but only at the request of both parties, was unlikely to materialize since the Tamil Tigers were officially banned in India as a terrorist group. The Indian prime minister was assassinated in May 1991 by a suicide bomber from the Tamil Tigers.

India had sent peace-keeping troops in 1987, but these were withdrawn in 1990 after heavy losses and after the leadership in Sri Lanka changed, and an agreement brokered by India was not implemented. (IHT 23-05-00) 
In late May 2000 the Indian government said that the Indian navy was prepared to evacuate 30,000 Sri Lankan troops from the Jaffna Peninsula at the request of Sri Lanka, if a cease-fire were declared. (IHT 26-05-00)

\section{Hmong insurgents in Laos}

Remnants of an anti-Communist militia consisting of Hmong minority people, who populate both sides of the Lao-Thai border, had remained active in Laos after the Vietnam War. This militia was originally recruited by the US CIA, and the US had later granted asylum to tens of thousands of its members. In the late 1970s and 1980s they were with Vietnamese support largely eliminated, but an influx of weapons smuggled in across the Thai border by Hmong emigrés from the US had enabled the group to escalate their activities again in 2000 .

It was reported in early June 2000 that Vietnam was intervening militarily to help the Laotian government in its fight against the rebels. (IHT 03/04-06-00)

\section{INTERNATIONAL COURT OF JUSTICE}

\section{Pakistan v. India: Aerial Incident of 10 August 1999}

The Court on 21 June 2000 declared that it had no jurisdiction to adjudicate upon the dispute brought before it by Pakistan against India.

In founding the jurisdiction of the Court Pakistan relied on the General Act for Pacific Settlement of International Disputes of 1928, on the declarations of acceptance of the compulsory jurisdiction of the Court made by the parties, and on Article 36 paragraph 1 of the Court's Statute, particularly where the provision refers to "matters specially provided for in the Charter of the United Nations".

As to the 1928 Act the Court concluded that India could not be regarded as having been party to that Act. Concerning the declaration under Article 36 paragraph 2 of the Statute, the Court observed that India's declaration contained a reservation according to which "disputes with the government of any state which is or has been a Member of the Commonwealth of Nations" were excluded from the Court's jurisdiction. It followed that the Court had no jurisdiction on the basis of the declarations made. With regard to the third basis for jurisdiction relied on by Pakistan, the Court stated that the UN Charter contained no specific provision of itself conferring compulsory jurisdiction on the Court, and, consequently, the Court did not accept Article 36 paragraph 1 as a basis for its jurisdiction. (Press Communiqué 2000/19)

\section{INTERNATIONAL CRIMES AND THEIR ADJUDICATION}

See also: Self-determination, infra at 413)

\section{Cambodia}

The UN and Cambodia had been negotiating for some time about the setting up of a genocide tribunal for Khmer Rouge leaders. No agreement had been reached because according to the UN assistant secretary-general for legal affairs there was 
a conceptual difference between the Cambodian notion of a tribunal for the purpose, on the one hand, and the international legitimacy that could be obtained with it on the other. The UN had agreed to hold a joint trial in Cambodia but wanted firm control of the proceedings because the courts in Cambodia were "obviously lacking" international standards of justice. On the other hand, Cambodia was against a majority of foreign judges, which would constitute a threat to its sovereignty, and insisted that UN appointees should play only a supporting role in Cambodian-controlled proceedings.

On another point the UN had demanded that no one be exempt from trial, but several Khmer Rouge leaders had defected to the government and there were moves to limit the number of indictments so as not to disturb the hard-won peace. (IHT 01-09-99)

In order to salvage UN involvement the US proposed a tribunal with three Cambodian judges and two UN-appointed judges, of whom one would have to agree with any verdict passed by the tribunal. The Cambodian prime minister agreed in principle to the proposal. (IHT 20-10-99) A law on the matter was drafted by the government in early January 2000 . The law would allow foreign judges and prosecutors in "extraordinary chambers" in Cambodian courts, but would leave the Cambodian counterparts firmly in charge.

Initially the UN Secretary-General remained firm, urging the creation of an independent public prosecutor and a majority of UN-appointed judges, but in May 2000 the UN conceded to Cambodia the right to appoint one of two prosecutors and agreed that the panel of judges would comprise three members from Cambodia and two nominated by the UN. If the two prosecutors were unable to agree on an indictment, the five judges would act as arbitrators. For an indictment to be overturned, four of the five judges would have to agree. (IHT 22-12-99, 07-01, 03-02, 10-02, 26-05-00)

A military court in Cambodia charged the former Khmer Rouge guerrilla chief TA MOK with genocide on 7 September 1999. The charge was brought under a new law enabling the authorities to hold suspects in detention without trial for longer than the usual six-month limit. The law allowed detention for up to three years if the person were charged with genocide, war crimes or crimes against humanity. (IHT 08-09-99)

\section{INTERNATIONAL ECONOMIC AND TRADE RELATIONS}

(see also: Inter-state relations: Vietnam - US)

\section{Sino-Japanese agreement on China's bid to WTO membership}

The Japanese prime minister met his Chinese colleague in Beijing on 9 July 1999, at which meeting a formal agreement was signed on the issue of China's application for WTO membership. The agreement effectively affirmed Japan's endorsement. (IHT 09-07-99) 


\section{Sino-US comprehensive agreement}

After thirteen years of negotiations China and the US on 15 November 1999 reached a comprehensive agreement to open China's economy to foreign competitors in return for China's entry into the WTO. In order to obtain membership China still had to reach agreement with the EU, Canada and a number of developing countries.

Alhough the US Congress did not need to give its approval for China to proceed with its application for WTO membership, such approval by way of the grant of "normal trading status" (formerly known as most-favoured nation status) would be necessary for the agreement to take full effect in the bilateral relations of the two countries. (IHT 16-11-99) On 24 May 2000 the US House of Representatives granted this status to China by voting in favour of the so-called China Trade Bill. (IHT 26-05-00)

\section{Sino-EU accord on China's application for WTO membership}

China and the EU on 19 May 2000 reached a market-opening agreement that removed the last obstacle to China's fourteen-year effort to obtain admission to the WTO. (IHT 20/21-05-00)

\section{INTER-STATE RELATIONS: GENERAL ASPECTS}

\section{East Asian cooperation}

The heads of state/government of ASEAN member states and China, Japan and South Korea, meeting on 28 November 1999 for the third time since 1997 (see 7 Asian YIL 441, 8 Asian YIL 256), agreed on a framework for wide-ranging cooperation and, consequently, issued a Joint Statement on East Asian Cooperation. (IHT 29-11-99) (text infra at $\mathbf{X X X}$ )

\section{North-east Asian summit talks}

On the sidelines of the third ASEAN Informal Summit Meeting at Manila the leaders of China, Japan and South Korea held their first trilateral summit talks on 28 November 1999. They agreed on a proposal from the South Korean president for research institutes in the three countries to undertake a joint study to establish a framework for cooperation. (IHT 29-11-99)

\section{Afghanistan}

Russia and the US issued a joint statement in early June 2000, expressing concern over the "growing influence of extremist groups" in the region of Afghanistan. They urged the Taleban, which was in control of the country, to hand over OSAMA BIN LADEN to the US and to "dismantle the terrorist infrastructure" that allegedly was sending Islamic fighters to unsettled areas such as Kashmir and Chechnya. At the same time Russian officials warned that they might launch preventive air strikes against suspected military training camps in Afghanistan. The US had bombed several such targets in August 1998, in retaliation for the bombings of the US embassies 
in Kenya and Tanzania. (see 8 Asian YIL 284) China, Kazakhstan, Kyrgyzstan and Tajikistan joined Russia in calling for strict implementation of the UN Security Council resolution 1267 (1999) which banned international flights and froze official Afghan assets abroad.

The Taleban dismissed the charges that it was training or arming Islamic terrorists. It had also repeatedly refused to hand over USAMA BIN LADEN to Western authorities, saying he was its guest and it had seen no proof of his involvement in terrorism abroad. Instead, it offered to have him tried in Islamic courts in Afghanistan or another Muslim country.

Pakistan's attitude was rather ambiguous. It made several statements in early June 2000 to the effect that friendly relations with the Taleban were important to Pakistan's security and that Pakistan was reluctant to interfere with Afghan internal affairs. Pakistan was one of three countries that had recognized the Taleban government. (IHT 07-06-00)

\section{China - India}

The two states held their first two-day formal talks on global and regional security issues at Beijing in early March 2000. (IHT 08-03-00)

\section{China - Israel}

The Chinese president paid the first official visit to Israel by a Chinese leader on 12 April 2000.

Israel had agreed in 1997 to equip a Chinese-owned aircraft with an advanced Israeli "Phalcon" early warning system to monitor the movement and communications of planes, ships and ground troops over an area of 250 miles. It was similar to the US AWACS system. The US had strongly objected to the deal although it had not raised objections when Israel gave notification of its plans in 1996.

It was said that Israel had several goals with its arms sales to China, which started after the two countries began to have unofficial contact in the late 1970s. One was to woo China away from support for the Palestinian cause, including the sale of arms. A second goal was to ensure China's support for the Middle East peace process, and a third was to minimize Chinese arms exports to countries hostile to Israel, such as Iran and Syria. It was said that the effort had borne fruit, as China had allegedly dropped support for UN resolutions damaging to Israel, and had allegedly curtailed direct transfers of technology to such countries. (IHT 12-04, 13-04-00)

\section{China - Japan}

Against the backdrop of the result of the Taiwanese presidential election in March 2000 the Japanese foreign minister said that Japan would continue to maintain "its exchanges of a private and regional nature with Taiwan as non-governmental working relations", while indicating that it expected China to respond in kind to the new Taiwanese president's conciliatory overtures. (IHT 20-03-00) 
China - US

(see also: Divided states: China: US attitude)

Military contacts were frozen from the 7 May 1999 bombing of the Chinese embassy in Belgrade (see 8 Asian YIL 287) and were said to be unlikely to resume in the near future. China remained unconvinced by US explanations and wanted to see further details and progress on economic issues before resuming military contacts. (IHT 01-07-99)

The US government agreed 30 July 1999 to pay \$4.5 million to the families of those killed and wounded by the US bombing of the Chinese embassy in Belgrade on 7 May 1999. The money would be given to the Chinese government which would decide how to divide the funds among those involved. In an effort to avoid setting a precedent, it was said that "the payment will be entirely voluntary and does not acknowledge any legal liability". (IHT 31-07/01-08-99)

On 16 December 1999 the two sides reached agreement on compensation for the destruction of the embassy building and the damage done to US diplomatic facilities in China resulting from demonstrations against the Belgrade incident. The US would pay \$28 million and China \$2.87 million. (IHT 17-12-99)

It was reported on 10 April 2000 that the US Central Intelligence Agency had sacked an intelligence officer and reprimanded six managers for errors that led to the bombing. (IHT 10-04-00)

In early February 2000 China launched a strong protest against the passing by the US House of Representatives of a bill under the name of Taiwan Security Enhancement Act, despite the fact that the bill still had to pass the Senate and that the US government had already made it known that the president would veto the bill. The act would establish direct military communications between the the US and Taiwan, expand US training of Taiwanese military officers and force the US government to make public Taiwanese requests for weapons. (IHT 03-02-00)

In early June 2000 China agreed to start formal discussions with the US on arms control and non-proliferation issues. (IHT 07-06-00) Meanwhile US officials rejected China's warning of a new arms race if the US proceeds with plans to build a missile defence system, with the US claiming that this was needed for stability in Asia and enabling the US to support and defend its friends and allies in the region; it referred to possible attacks by countries such as Iran and North Korea. China held the opinion that the system would upset the strategic balance between the US and China. (IHT 08-06, 23-06-00)

\section{China - Vatican}

In a move that publicly snubbed the Roman Catholic Church, the Chinese Patriotic Catholic Association on 6 January 2000 ordained new bishops on the same day that the Vatican ordained theirs, but not Chinese). The Chinese Patriotic Catholic Association does not recognize the Pope's authority to appoint bishops and had about seventy bishops of its own. Some of them had also been ordained by the Vatican. (IHT 05-01-00) 


\section{Iran - US}

The US government announced on 3 December 1999 that it would waive US sanctions against Iran by allowing the Boeing Corporation to supply parts needed by Iran's national airline. (IHT 06-12-99)

US intelligence reports said that Iran was increasing deliveries of arms to so-called "terrorist groups", such as the Palestinian Hamas and the Lebanese Hezbollah, as well as coordinating activities among such organizations "and may be plotting attacks on Israel or Jewish targets abroad". Against this backdrop it was said that the US had no plans to change their policy of "containing" Iran through economic sanctions, though at the same time seeking dialogue and promoting "people-to-people exchanges". Besides, a classified FBI report of spring 1999 advanced long-held US suspicions of Iranian involvement in the June 1996 bombing of a US military housing complex ("Khobar Towers") in Saudi Arabia. (IHT 06-12-99)

However, on 17 March 2000 the US Secretary of State announced in a speech that the US would lift a ban on the import of Iranian luxury goods, would seek a legal settlement that could free Iranian assets frozen since the 1979 Islamic revolution and, it was reported, even "essentially apologized for past policy toward Iran, including the CIA-backed coup in 1953" [against the MOSSADEQ government]. The Iranian government responded by saying that it found the speech positive and that Iran would reciprocate by opening its borders to US food and medicines. However, official talks were considered unrealistic. (IHT 20-03-00)

\section{Japan - North Korea}

In early August 1999 the Japanese foreign minister said that Japan might respond to a new North Korean missile test by severing money transfers from Koreans living in Japan. (IHT 09-08-99)

The North Korean pledge to refrain from launching another missile (see infra, at 408) brought the two countries to agreement on 2 December 1999 to resume talks on setting up diplomatic relations as well as on restarting Japanese food aid. Food aid was stopped after North Korea fired a missile over Japan in 1998 (see 8 Asian YIL 292) but the Japanese government stated on 14 December 1999 that it would lift the restrictions. Earlier talks on normalizing relations started in early 1991 (see 2 Asian YIL 330) but stalled in November 1992 after Japan accused North Korea of kidnapping a Japanese woman. (IHT 03-12, 10-12, 15-12-99)

Talks involving Red Cross and foreign ministry officials started 20 December. (IHT 21-12-99) The Red Cross officials reached agreement on food aid and other humanitarian issues, such as the fate of a number of Japanese missing persons believed to be held in North Korea and that of Koreans who had disappeared from the northern part of Korea before 1945. (IHT 22-12-99) During the inter-Red Cross talks in Beijing North Korea pledged on 13 March 2000 that it would help search for missing Japanese allegedly abducted by North Korean agents in the late 1970s.

The talks on establishing diplomatic relations were resumed in Pyongyang in early April 2000, but suffered a setback on 5 April when North Korea demanded that Japan first discuss paying compensation for abuses committed when it was ruling Korea as a colony, which was refused by Japan. (IHT 31-01, 08-03, 14-03, 06-04-00) 
On 19 June 2000 North Korea said it was prepared to resume the talks. (IHT 20-0600)

\section{North Korea - Europe}

North Korea proposed holding foreign ministers' meetings with European countries on the sidelines of the UN General Assembly meeting in the autumn of 1999. North Korea had held a working-level "political dialogue" with the European Union in December 1998, during which it had asked increased humanitarian aid. However, the dialogue reached deadlock as the EU urged North Korea to improve its human rights record and to reduce missile threats. (IHT 26-08-99)

In March 2000 diplomatic relations were established with Italy, the first of the Group of Seven countries to do so. [Italy had started to opening up to countries which in Western political parlance have been called "rogue states", such as Libya and Iran.] (IHT 17-03, 18/19-03-00)

\section{North Korea - Russia}

The two countries signed a friendship treaty on 9 February 2000 which sought to heal relations that were strained after the then Soviet Union established diplomatic relations with South Korea in 1990 . The treaty replaced a mutual aid agreement and omitted previous provisions on political and military alliance. (IHT 10-02-00)

It was announced in June 2000 that the Russian president would visit North Korea in July, the first ever visit by a Soviet or Russian leader. The announcement followed a meeting of the Russian and US presidents, and caught the US by surprise. (IHT 10/11-06-00)

\section{North Korea - US}

(See also: Missile technology - North Korea; Sanctions)

The US in late June 1999 expressed its suspicion of renewed North Korean preparations "indicating a potential launch of a ballistic missile in the future". The Deputy Assistant Defense Secretary said that "we would view any potential launch of either a satellite or a missile [as] a very serious act with very real consequences for US foreign policy towards North Korea".

The US and South Korea had earlier in late August of 1998 warned North Korea not to repeat the alleged firing of a missile with a potential range of more than 4,000 miles. (see 8 Asian YIL 292) (IHT 01-07-99)

Nevertheless, North Korea said, as it had on 3 August 1999, that it would push ahead with test-firing a missile if the US stepped up its pressure. The spokesman of the foreign ministry said, inter alia, that "whether we test-fire a satellite or a missile is a legitimate, independent right to be exercised by a sovereign state". (IHT 04-08-99)

On 27 July 1999 a report on Korea was issued by a task force of the (US) Council on Foreign Relations. The report emphasized the necessity for the continuation of a policy of engagement with North Korea in order to influence the latter. Even if North Korea conducted a new missile test, it should not be considered a departure 
from the past, but rather an attempt by a fearful regime to assert its ability to protect itself. Moreover, such a test would not violate any existing US-North Korean agreements. The report also urged that humanitarian food aid be continued, that the socalled PERRY proposals be left on the table, that the implementation of the 'agreed framework' of 1994 (see 5 Asian YIL 545) should go on, and that channels for fourparty talks should be kept open. (IHT 28-07-99)

The PERRY proposals referred to WILLIAM PERRY, the former Secretary of Defense who was assigned by the US president to oversee a full review of policy toward North Korea and sent on a mission to North Korea in May 1999 (see 8 Asian YIL 282). The proposals were presented by a committee led by Mr. PERRY as late as September 1999 and released on 12 October 1999. They recommended that the US and its Asian allies try to coexist with North Korea rather than seek to undermine its government or to promote internal reform. An attempt to achieve the demise of the North Korean government would take too long and had no guarantee of success. The proposals included, inter alia, the lifting of trade sanctions and the beginning of a formal recognition of North Korea at a "markedly faster rate" in return for a halt to its testing of missiles and an end to its export of missile technology to the Middle East and Pakistan. The recommended strategy included the following points:

- to seek assurance that North Korea had no nuclear weapons program and cease testing, production, deployment and export of long-range missiles;

- $\quad$ to normalize relations and relax trade sanctions;

- $\quad$ to preserve the 1994 Agreed Framework;

- to continue to act in concert with Japan and South Korea.

(IHT 27-08, 16-09, 14-10-99)

In return for the 1999 trip to Pyongyang by Mr. PERRY, a visit by a high-ranking North Korean official to the US was to take place, preparations for which took place in early March 2000. (IHT 09-03-00) Later in the month, however, North Korea said it would not send a high-level delegation unless the US removed it from a list of countries allegedly sponsoring terrorism. (IHT 29-03-00)

In late May 2000 it was announced by the US president that US-North Korean talks would be resumed in June at Kuala Lumpur, inter alia on the issue of more than 8,100 US soldiers listed as missing in action in the Korean War. Since 1996 joint operations had resulted in the identification and repatriation of the remains of about 40 US soldiers. (IHT 30-05-00) [It was later reported that the resumption of talks would take place in July instead of June. (IHT 29-06-00)]

On 17 September 1999 the US announced that it was to lift much of the more than four-decade-old US trade embargo in response to what the US said was a North Korean pledge not to proceed with a planned missile test-firing (see infra, at 408). This ranked among the most dramatic US gestures of conciliation since the end of the war in 1953. (IHT 18/19-09-99) The sanctions were actually eased on 19 June 2000. US restrictions would remain on sales of military materiel, some high-technology goods and items with "dual" use. The classification as a supporter of terrorism would remain, and the US would continue to oppose loans by global financial institutions. (IHT 16-06, 20-06-00) 
Despite the conciliatory spirit of the inter-Korean summit meeting shortly before (see supra, at 393) North Korea on 18 June 2000 accused the US of increasing the danger of war on the Korean Peninsula. The accusation was in response to a US statement immediately after the summit meeting that it had no plans to withdraw its forces from South Korea. The accusation apparently referred both to the 37,000 US troops stationed in South Korea and to the US plans to set up a missile defence shield. (IHT 19-06-00) The South Korean foreign minister stated that even after an official peace had been agreed between North and South Korea, American troops would "continue to play their role as a guarantor of the balance of power". (IHT 24/25-06-00)

\section{South Korea - Japan}

A process of reconciliation, driven by a variety of factors, such as shared economic interests and a shared feeling of threat from North Korea, had set in between the two countries. The first major step in the reconciliation was the written Japanese apology for its 36-year colonization of Korea (see 8 Asian YIL 281). In August 1999 the two countries held a joint naval drill, and in August 1999 the Japanese prime minister for the first time visited a stone tower in Hiroshima, built in 1970, dedicated to Korean victims of the atom bomb. Besides, there were the growing exchanges in various fields. However, Japan still refused to compensate Korean women who worked as "comfort women" during the Pacific War (see 8 Asian YIL 314) and it had not yet agreed to compensate Koreans who had fought for Japan in that war. Many among the 600,000 people in Japan of recent Korean descent kept feeling discriminated against in various areas and prejudices against Koreans persisted. (IHT 21-09-99)

\section{South Korea - US}

The South Korean president met the US president on 2 July 1999. (IHT 01-07-99) Among other items, South Korea hoped it would achieve US approval for its missile program including a missile with a 300-kilometre range.

The current understanding with the US, dating from the time of US recognition of the CHUN Doo HwAN government in 1979, was that South Korea would not produce missiles with a range of more than 180 kilometres, or up to 20 kilometres from the North Korean capital Pyongyang (see 7 Asian YIL 462). South Korea had expressed its desire to join the 32-country Missile Technology Control Regime (see 1 Asian YIL 270) by which it had already pledged to abide. Under this Regime the maximum allowed range of missiles is 300 kilometres and a 500-kilogram payload.

Initially there was a feeling in South Korea that the US wanted to avoid antagonizing North Korea, which was confirmed by a response from the US State Department, insisting that diplomacy was the answer to regional tensions. Later, however, the US supported the South Korean desire and promised to work help "to accommodate their needs as far as their missile capabilities [are concerned]". (IHT 02-07, 30-07-99) 


\section{Sri Lanka - Israel}

It was reported in early May 2000 that Sri Lanka had decided to re-establish diplomatic ties with Israel which had been severed in the early 1970s. It was said that the move would help Sri Lanka benefit from the expertise of the Israeli arms industry. (IHT 05-05-00)

\section{Vietnam - US}

Twenty-four years after the end of the Vietnam War, agreement was reached on 25 July 1999 on a Bilateral Trade Agreement establishing fully normalized trade relations, after three years of negotiations. It would be signed later in the year. The agreement addressed trade in goods and services, protection of intellectual property and investment relations between the two countries, and conferred "normal trading status" (formerly called "most favoured nation status") to Vietnam vis-à-vis the US.

The agreement was due to be signed during the APEC meeting in September in New Zealand, yet the Vietnamese government failed to obtain the necessary approval to proceed. (IHT 11/12-09-99)

The US did not lift a trade embargo against Vietnam until 1994 and did not establish diplomatic relations until 1995. (IHT 22-07, 26-07-99)

\section{(NON-)INTERVENTION}

\section{Meeting with Dalai Lama}

China on 21 June 2000 protested at the fact that a meeting had taken place between the US president and the Dalai Lama. China considers Tibetan matters to be an internal Chinese affair, and therefore considered the meeting to be meddling in these affairs. (IHT 22-06-00)

\section{JAPAN'S MILITARY ROLE}

\section{Japan-US missile defence}

The US and Japan in July 1999 agreed on measures to intensify cooperation on defence against ballistic missiles in the face of the North Korean apparent plans to test-fire another long-range missile (see also 8 Asian YIL 291). A memorandum of understanding was signed on 16 August 1999 on jointly developing the means for spotting and shooting down missiles flying within a 1,860 mile radius, before they could hit Japanese territory. The cooperation was described by the Americans as an element of "theater missile defence", a term referring to defence of a wide expanse of territory extending beyond Japan, whereas Japan preferred to use the term "ballistic missile defence", referring to the just defence of Japan and the waters around it. (IHT 29-07, 17-08-99)

According to a senior Japanese official, a strike against foreign bases from which missiles were aimed at Japan would not be a violation of Article 9 Japan's "Peace Constitution" forbidding the country from waging war overseas. It would be the 
exercise of the right to self-defence when it was confirmed that the other side had embarked on an action to attack Japan. (IHT 29-07-99)

\section{LAW OF THE SEA}

\section{Indonesian archipelagic sea lanes}

On 19 May 1998 the 69th Session of the Maritime Safety Committee of the International Maritime Organisation adopted the Indonesian proposals for the designation of three sea lanes (Archepelagic Sea Lanes, Alur Laut Kepulauan Indonesia or ALKI) through the Indonesian archipelago for transit between the Indian Ocean and the South China Sea, the Sulawesi Sea and the Pacific Ocean respectively.

\section{MARITIME DELIMITATION}

See: Borders, border disputes and border incidents

\section{MIGRANT WORKERS}

\section{Filipino workers in Taiwan}

Taiwan put a three-month hold on labour permits for new Filipino workers on 1 June 2000. There were 112,000 Filipino workers in Taiwan, accounting for 37 per cent of foreign workers in Taiwan, second only to Thai labourers. (IHT 02-06-00)

\section{MILITARY ALLIANCE}

(See also: Japan's military role)

\section{Japan-US cooperation in missile development}

The two countries expected to reach agreement in August 1999 on research toward developing a ballistic missile as part of a joint defence system. Under the draft memorandum of understanding the parties would jointly design a missile with a kinetic warhead capable of shattering an enemy missile without exploding. Military analysts even speculated about a future US-Japan joint command and saw the new "Guidelines" for US-Japanese defence cooperation (see 6 Asian YIL 426; 7 Asian YIL 458) as possibly providing a basis for such a development. (IHT 07/08-08-99)

\section{MILITARY COOPERATION}

\section{Japan - South Korea}

In early August 1999 Japanese and South Korean navy ships and air force participated in joint manœuvres, the first joint military operations since Japanese colonial rule. The exercise was apparently intended as a warning to North Korea 
in connection with the latter's alleged plan to carry out a new missile test-launching (see infra, at 407). South Korea was persuaded to participate after Japan had issued a written apology for Japan's colonial past. (see 8 Asian YIL 281). In order not to provoke North Korea the manœuvres were held as far away from North Korea as possible: in the straits between the southern Japanese island of Kyushu and the Korean island of Cheju. (IHT 06-08-99)

\section{Indonesia - US}

It was reported in February 2000 that the US had quietly resumed training Indonesian military officers in the US, which was suspended in 1999 after the violence that engulfed East Timor (see infra at 413) While US officials stressed that they had not resumed full military-to-military relations with Indonesia (IHT 19/20-02$00)$, the commander-in-chief of the US forces in the Pacific went to Indonesia on 2 April 2000 to discuss this full resumption. Two conditions were, on the one hand, accountability for the actions of elements of the Indonesian military in East Timor and on the other ensuring that those among the refugee population in West Timor who wanted to return to East Timor could do so, and that the others were moved into a more permanent situation in Indonesian territory in order to prevent the development of a breeding ground for trans-border militia activity. (IHT 01/02-04-00)

The resumption was confirmed in May 2000 when Indonesian military observers were invited to participate in joint exercises in Thailand and by completing plans to hold the first joint exercises between US and Indonesian armed forces in July 2000. (IHT 25-05-00)

\section{MISSILE TECHNOLOGY}

(See also: Japan's military role; Military alliance)

\section{North Korea}

(See also: Regional security)

In early July 1999 there were rumours about North Korean plans to carry out another missile test (see for previous incidents: 8 Asian YIL 291). In response to these reports the South Korean and US presidents delivered a joint warning to North Korea on 2 July 1999 not to proceed with the plans which were not, however, confirmed by North Korea. While pronouncing itself against the possibility of North Korean missile tests US sources also commented that the North Korean missiles were believed to be fairly inaccurate and would thus not be very useful militarily. (IHT 05-07-99) Later in the month "diplomatic and security officials" were reported as saying that North Korea was proceeding with its plans, and that these involve a longrange missile ("Taepo Dong-2") with a range of up to 6,000 kilometres. (IHT 23-0799)

On the occasion of the meeting of the ASEAN Regional Forum (see 3 Asian YIL 440; 4 Asian YIL 505) on 26 July 1999 the foreign ministers of the US, South Korea and Japan said that North Korea would be hit with punitive economic sanctions 
and lose a major opportunity to improve relations with the three countries if North Korea proceeded in testing another, new type of ballistic missile. They warned that the consequences of missile proliferation for peace and stability in Asia and the Pacific were so grave that North Korea would have to be punished, despite the possible risk of war. The US Secretary of State said that this applied irrespective of "whether [the launch be] declared ... a missile test or an attempt to place a satellite in orbit". (IHT 28-07-99)

The diplomatic measures to discourage North Korea were not to prevent an immediate threat, yet the test would subtly but significantly change the existing pattern of relations that had kept the region stable. (IHT 12-08-99)

On 18 August 1999 North Korea, rather unexpectedly, said that "[a]s regards the missile issue, we are always ready for negotiations if the hostile nations honestly ask for it out of an intention to alleviate our concern". The foreign ministry said that North Korea had developed missiles by way of self-defensive measure because the US posed a threat by keeping military forces in South Korea and because it still harbored intentions to invade North Korea. The position taken was phrased by a North Korean politician as follows: "If the visitor comes and offers us a cake, we'll respond with a cake. But if somebody comes with a sword or knife, we'll respond with a knife." (IHT 19-08-99) The two sides, possibly as a response to appeals by the US envoy PERRY (see supra, at 403) agreed in late August 1999 to meet and talk in Berlin for four days, beginning 8 September. (IHT 27-08, 30-08-99)

After five days of discussions North Korea informally agreed to a de facto freeze of its missile-testing programme. In exchange, the US agreed to encourage the process of developing normal relations and of eventually removing sanctions that had banned commercial and other exchanges (see supra, at 403). The two delegations announced in a brief statement that their countries had pledged "to preserve a positive atmosphere conducive to improved bilateral relations and to peace and security in North-east Asia and the Asia-Pacific region". This marked the second time (with the 1994 Agreed Framework) that the US offered a situation valued by North Korea in exchange for commitments to back off from a potentially dangerous programme. (IHT 13-09, 18/19-09-99) On 24 September the North Korean government announced publicly that it would refrain from further missile tests while talks with the US were under way, "in order to create a more favourable atmosphere".

The North Korean-US talks would be resumed in early October 1999. (IHT 25/2609-99).

\section{China}

China launched a long-range "Dong Feng-31" missile on 2 August 1999. According to "military experts" this missile could carry a single nuclear warhead about 8,000 kilometres. The launch occurred during a most delicate period of Mainland-Taiwan relations (see supra, at 390). (IHT 03-08-99) 


\section{MONETARY MATTERS}

\section{Asian cooperation}

On the sidelines of the annual meeting of the Asian Development Bank in Thailand in early May 2000, a broad grouping of East Asian states, including ASEAN and Japan, South Korea and China, agreed to work toward curbing economic turmoil in the region by defending one another's currencies from speculative attack. For that purpose they expanded an existing network of arrangements (see 8 Asian YIL 293) and named it the Chiang Mai Initiative.

The plan called for a network of bilateral currency swap-and-repurchase arrangements and implied the establishment of a system of pooled reserves from which a central bank could draw when its currency comes under attack from speculators. However, the plan did not specify concrete mechanisms or deadlines for implementation and was, therefore, essentially outmoded and inadequate. In fact Hong Kong had already set up a network of bilateral repurchase agreements among eleven central banks in 1995 (see ibid.).

While efforts were made to distinguish the plan from the aborted attempt to set up an Asian Monetary Fund (see ibid.) this latter idea received strong support from, inter alia, Malaysia. A Japanese former deputy finance minister made an impassioned call for the establishment of such a fund, saying "If unaffected countries do not have a political incentive to contribute their own money, they should say so instead of using the 'moral hazard' argument as an excuse". (IHT 08-05-00)

\section{NATIONALITY}

See: Refugees

\section{NUCLEAR ENERGY MATTERS}

\section{Implementation of the 1994 North Korean-US agreement}

South Korea on 2 July 1999 signed an agreement with Korean Peninsula Energy Development Organization (KEDO, see 5 Asian YIL 547) providing for a contribution of $\$ 3.22$ billion in the financing of two nuclear reactors for North Korea under the 1994 Agreed Framework between North Korea and the US. (see 5 Asian YIL 545) The agreement acquired parliamentary approval on 12 August 1999. The consortium agreement on the construction of the power plants was signed on 15 December 1999.

Japan agreed to contribute $\$ 1$ billion to the same project, and the European Union $\$ 87.7$ million. (IHT 3/4-07, 13-08, 16-12-99) Meanwhile Japan had threatened to freeze its contribution if North Korea proceeded with plans for a new missile test (see supra, at 407), and North Korea itself threatened on 26 July 1999 to pull out of the agreement unless the US began to "show good faith" in the issue by lifting economic sanctions. It also rejected US moves to link the North Korean missile development programme to the provision of funds for the nuclear project. The foreign ministry was quoted as saying: "We, who are exposed to constant threat due to the 
US policy of isolating and stifling the DPRK, are left with no option but to increase our own defence capabilities and develop missiles as its means." (IHT 27-07-99)

\section{North Korean nuclear facility}

The South Korean daily Chosun Ilbo reported on 7 July 1999 that according to an unidentified South Korean government source North Korea was building a new nuclear facility at Yongjudong, 20 kilometres from the Chinese border. (IHT 08-0799)

\section{Denial of North Korean uranium imports}

North Korea on 7 February 2000 denied media reports (Washington Times) that it might be importing uranium from the Democratic Republic of the Congo to manufacture nuclear weapons. (IHT 08-02-00)

\section{North Korean complex at Kumchangri}

Under a March 1999 agreement (see 8 Asian YIL 297) the US announced on 15 May 2000 that a US team would visit an underground site at Kumchangri, North Korea for a second time as of 23 May 2000. The aim of the visit would be to confirm the findings of the first visit of May 1999 that the complex did not constitute a violation of the 1994 accords (see 5 Asian YIL 471, 545) (IHT 16-05-00)

\section{Taiwan radioactive wastes}

It was reported that China (the China Nuclear Energy Industry Corporation) and Taiwan (Taiwan Power Co.) were negotiating a multi-billion dollar deal under which radioactive wastes from Taiwanese nuclear power plants would be disposed of on the mainland against payment and technical aid to the mainland nuclear power industry. The proposed deal would involve low-level wastes, such as power-plant equipment that had become radioactive, and not spent nuclear fuel rods that could possibly be reprocessed into bomb-grade materials.

In 1997 Taipower announced an agreement with North Korea, but this deal was cancelled after concerns were raised by South Korea, and the US and North Korea became uncooperative. (IHT 14-03-00)

\section{ORGANIZATION OF THE ISLAMIC CONFERENCE (OIC)}

\section{Summit Conference, Tehran 9 November 1997}

The Conference produced a Tehran Declaration in which it condemned Israel as a "terrorist state", demanded the surrender of all occupied Arab land, and condemned the US 1996 Iran-Libya Sanctions Act, declaring that the Muslim countries "reject unilateralism and the implementation of extra-territorial laws, and call on all states to consider the so-called D' AMATO law null and void" (see 8 Asian YIL 213 et seq.). 
It reaffirmed their commitment to a code of conduct to fight terrorism as approved at the OIC summit at Casablanca in 1994 and called for an international conference on terrorism under UN auspices [cf. the later International Convention for the Suppression of Terrorist Bombings of 1998]. The OIC states "strongly condemn terrorism in all its forms and manifestations, while at the same time recognizing the right of self-determination of those peoples living under colonial or foreign domination, or under foreign occupation". The emphasis on terrorism followed recent massacres in Algeria and the killing of 62 people at a tourist site in Egypt in November 1997.

The conference approved 142 political, cultural and economic resolutions. (JP 12-12-97) [The OIC is based in Jeddah, Saudi Arabia.]

\section{PIRACY}

\section{Cooperation on combating piracy}

Senior maritime officials from sixteen Asian countries met in Tokyo in late April 2000 to discuss piracy. The idea of cooperation on combating piracy was raised by the Japanese prime minister at the ASEAN summit meeting at Manila in November 1999. Japan proposed a regional coast guard to combat piracy in the Strait of Malacca and Singapore as well as in the South China Sea, consisting of China, South Korea, Indonesia, Malaysia, Singapore and Japan. The force would conduct joint monitoring activities to protect the environment and resources in waters beyond state control, as well as to combat illegal activities that span international maritime boundaries, including illegal fishing, illegal entry and piracy. Examples of bilateral cooperation of a similar type are those between the US and Russia in the Bering Sea, and between Indonesia and Malaysia and Singapore in the Strait of Malacca.

The meeting adopted two initiatives in which the regional maritime authorities pledged to share information on pirate attacks. (IHT 28-04, 29/30-04-00)

\section{REFUGEES}

\section{Bhutanese refugees in Nepal}

(See also: 2 Asian YIL 349; 6 Asian YIL 442)

After more than three years the two sides resumed their talks and reached agreement on a way to identify Bhutanese citizens from among nearly 100,000 refugees who had been in UN-run camps in Nepal for the past nine years. (IHT 17-09-99)

\section{Chinese policy on North Korean refugees}

It was reported that Chinese policy toward North Korean refugees had tightened since 1999. Chinese border units had stepped up patrols, and the number of persons forcibly repatriated to North Korea had increased. In the year 2000, by late April 1,000 people had already been sent back to North Korea. China had been arguing 
that the North Koreans who came to China were not refugees but economic migrants. (IHT 29/30-04-00)

\section{REGIONAL SECURITY}

\section{ASEAN Regional Forum statement on North Korea}

In the context of the Sixth ASEAN Regional Forum meeting on 26 July 1999, following the annual ASEAN foreign ministers conference, the participating ministers of the 22 Asian, Pacific (Canada, US, Australia, and New Zealand) and European countries (represented by the EU) issued a statement expressing concern that North Korean missile testing and development could "heighten tensions and have serious consequences for stability in the Korean Peninsula and the region".

North Korea is the only Asian country that has refused to join the forum and take part in regional talks to reduce tensions and build confidence. (IHT 27-07-99)

\section{SANCTIONS}

(see also Missile technology: North Korea, Organization of the Islamic Conference)

\section{Kazakhstan-North Korea jet fighter sale}

Kazakhstan had sold about forty jet fighters to North Korea. The US government was reviewing the matter and the possibility existed that sanctions would be applied through the reduction of economic aid. North Korea is one of seven countries labeled by the US as sponsors of terrorism, and US law prescribes sanctions against countries that provide "lethal military assistance" to any of them. (IHT 28/29-08-99)

\section{Myanmarese sanctions on Thailand}

In early October 1999 political dissidents from Myanmar occupied the Myanmarese embassy in Bangkok and took hostages. After a while the Thai authorities decided to release these dissidents. In reprisal Myanmar closed its border and suspended fishing rights, and said it would not lift the sanctions until the dissidents were arrested and prosecuted. The sanctions imposed a heavy burden on Myanmar itself as the cost of fuel and food in those parts of Myanmar that were dependent on trade with Thailand had risen sharply. (IHT 24-11-99)

\section{US state sanctions against Myanmar declared void}

(See also 8 Asian YIL 240-242)

The US Supreme Court in its ruling of 19 June 2000 overturned a 1996 Massachusetts law that barred most state purchases from companies doing business with Myanmar ("Burma Law"), ruling that it impinged improperly on federal government authority to make foreign policy. The court held that since the US Congress had specifically authorized the president to negotiate sanctions against Myanmar, such authority should not be limited by local action. (IHT 20-06-00) 


\section{SELF-DEFENCE}

See: Japan's military role

\section{SELF-DETERMINATION}

(See also: Organization of the Islamic Conference, supra at 410)

\section{East Timor}

(See also 8 Asian YIL 306-307)

In the context of the UN-sponsored vote to be held in August 1999 (see 8 Asian YIL 307) more than 300 unarmed UN police advisers and military liaison officers were deployed to the territory, in addition to some 600 polling officials (United Nations Assistance Mission to East Timor - UNAMET). Since the end of June proIndonesian militia had harassed and attacked UN mission personnel and outposts in several towns. (IHT 07-07-99) While Indonesian ministers tried to create a level playing field for the referendum by coming to East Timor and calling rival factions to stop escalating violence (IHT 13-07-99), one of the main East Timorese leaders urged the UN on 26 July 1999 to consider sending armed peacekeepers for the scheduled vote. (IHT 27-07-99) On the other hand the Indonesian foreign minister on 27 July 1999 accused the UN of bias in favour of independence for East Timor, citing that almost all of the 4,000 East Timorese recruited by UNAMET as its personnel were from the ranks of pro-independence supporters. (IHT 28-07-99)

In early August it was reported that the US, Australia and some European countries had started discussions with the UN on a contingency plan to send an armed peacekeeping force to East Timor. Such a move would, however, occur only if an Indonesian withdrawal triggered a conflict that could not be controlled by the unarmed UN mission. (IHT 03-08-99) Under the May 1999 agreement the UN was to be responsible for organizing the vote, but security was to remain an Indonesian responsibility. (IHT 28-07-99)] On 13 August 1999 the UN special envoy on East Timor told that the UN had endorsed a plan by leaders of rival East Timorese factions to set up a special council to promote "cooperation and reconciliation" in the territory after the vote. (IHT 14/15-08-99) Meanwhile, UN officials in East Timor warned that army-backed pro-Indonesian militias were planning for full-scale war if they lost the referendum on independence for East Timor. (IHT 24-08-99)

Even before the referendum the militias had already run wild in the capital Dili on 26 August, firing guns and setting fire to several buildings. Violence and bloodshed was also reported from other places. The Indonesian police, responsible for security during the campaign and on polling day, seemed unable to control the violence and in some cases even failed to intervene. As a result the UN Security Council on 27 August 1999 unanimously adopted a resolution increasing the police contingent and the military liaison group of the UN mission, and extending the mission's mandate. (IHT 27-08, 28/29-08-99)

One day before the vote was held representatives of the pro-independence guerrillas and the anti-independence militias announced a new peace agreement calling 
for a limitation in carrying firearms in public and calling on the police to arrest violators. However, on the same day the Indonesian military said that it might not be able to control the situation, despite the fact that under the agreement of 5 May 1999 Indonesia was committed to holding primary responsibility for security in the run-up to the vote. (IHT 30-08-99)

The referendum was held on 30 August 1999, with about 450,000 registered voters, but with one of the main independence leaders still held in detention at Jakarta and thus an absentee voter, and another still banned by Indonesia from setting foot in East Timor and also an absentee voter, in Australia. Against expectations the voting proceeded relatively smoothly, with the Indonesian police effectively enforcing security, and a turn-out estimated to be $90 \%$ or more. The result was certified by the UN Secretary-General and announced on 4 September 1999: 78.5 per cent had voted against the Indonesian autonomy offer, which implied a vote for independence. (IHT 31-08, 03-09, 06-09-99)

In contrast to the quiet on referendum day, the militias seemed to reappear on the scene with various acts of violence the following days, escalating calls for an international peace-keeping force. (IHT 01-09, 02-09-99) In a surprising turn-around Indonesian military officials suggested they would accept an international peacekeeping force if the voting results showed that the majority had voted for independence; civil war erupted. Meanwhile, the situation continued to deteriorate and Indonesia sent additional troops to restore order. There were an estimated 6,000 East Timorese in the Indonesian army in the territory, and in addition there were about 1,000 East Timorese serving in the Indonesian police force based in the territory. There were fears that desertions took place among these East Timorese who then joined forces with the anti-independence militias. (IHT 03-09, 4/5-09, 07-09-99) The situation led the UN special envoy for East Timor, JAMSHEED MARKER, to observe: "It is very clear today that the Indonesian government has failed in its responsibility to maintain adequate security." In a vain attempt to retain control over the situation Indonesia imposed martial law on the territory on 7 September 1999.

Pressure for international intervention mounted, with Portugal apparently taking the leading role and Australia putting troops on emergency alert for the purpose. The UN Secretary-General gave Indonesia 48 hours in which to restore order in Timor before international measures would be considered. Besides, a five-member delegation from the UN Security Council arrived in Indonesia on 8 September to press for quick action. The general opinion was that if Indonesia was not able to quell the chaos, it should ask the international community to step in, thus avoiding an uninvited "invasion". Moreover, the size and importance of East Timor in the world compared with those of Indonesia clearly played a role in the consideration of measures. (IHT 07-09, 08-09-99) The situation meanwhile deteriorated further, the imposition of martial law appeared to have no effect, and there was mounting suspicion of the complicity of the Indonesian forces in the violence. Nevertheless Indonesia kept resisting the idea of foreign peacekeeping forces entering the territory before it had ratified the vote for independence as the result of the referendum. The clear impression was that the Indonesian perception of what was going on in the territory was quite different from that of the outside world. (IHT 09-09, 10-09-99) 
On 10 September 1999 the Indonesian chief of the armed forces admitted that he had lost control of some troops who were emotionally committed to retaining East Timor. On the same day the UN Secretary-General urged Indonesia to accept a peace-keeping force lest it face responsibility for "what could amount to crimes against humanity", and recalled that several states in the region, including Australia, New Zealand, the Philippines and Malaysia had assured him of their willingness to take part in an international force to help Indonesia fulfill its responsibility to bring order and security. (IHT 11/12-09-99) On 11 September the Indonesian president conceded that Indonesian forces were unable to control the continuing violence and invited the UN to send a peace-keeping force to the territory, to work together with the Indonesian armed forces. (IHT 13-09-99) This coincided with moves to ensure that the force would be under Asian command and have a majority of Asian troops. (IHT 14-09-99)

The next day, 12 September, the Indonesian president also accepted a proposal from the UN High Commissioner for Human Rights for the creation of an international commission of inquiry consisting of Indonesian and foreign members, to investigate possible atrocities and look for evidence of human rights violations in East Timor. Such an inquiry could lead to the creation of a war crimes tribunal. (IHT 14-09, 20-09-99)

The UN Security Council, invoking Chapter VII of the UN Charter, finally adopted resolution 1264 on 15 September, authorizing a multinational force to "use all necessary means" to restore peace and ensure that the territory moves toward independence. It also demanded that those responsible for the violence be brought to justice. (IHT 16-09-99) The multinational (not "UN"-) force ("Interfet", International Force in East Timor) was to be replaced as soon as possible by a UN peacekeeping operation. Australia was to lead the multinational force, with a Thai and a Malaysian officer as deputy commanders. The following offers for contribution were made: Australia (troops and navy ships), Argentina (troops), Bangladesh (troops), Brazil (policemen), the UK (troops, destroyer, aircraft and funds), Canada (troops), China (civilian policemen), EU (funds), Fiji (troops), Finland (funds), France (troops and a frigate), Italy (troops, aircraft and a hospital vessel), Japan (funds), South Korea (troops), Malaysia (officers and a few soldiers, after initial opposition to Australia's role but consenting after Indonesian and UN request), New Zealand (troops, navy vessels and aircraft), Norway (officers), Pakistan (troops), the Philippines (troops and non-combat personnel), South Korea (troops), Singapore (medical personnel and logistics support), Sweden (civilian police officers and funds), the US (troops and navy support). (IHT 17-09, 18/19-09-99) It was later reported that Japan had allocated $\$ 100$ million to supporting Interfet and the future UN peacekeeping force, in order to help developing (Asian) countries to take part. Other UN members would have to agree to pay the remaining $\$ 500$ million of the estimated cost of the future UN operation. (IHT 05-10, 07-10-99)

The intervention force started to enter the territory on 20 September 1999, with the Indonesian forces handing over factual control of the territory a week later. A token force of 1,500 Indonesian soldiers was left behind pending formal transfer of the territory to UN jurisdiction after endorsement of the referendum result by the 
Indonesian People's Consultative Assembly (“MPR”) (IHT 28-09, 05-10-99) which took place on 20 October 1999. These troops departed on 31 October 1999. (IHT 01-11-99)

According to the International Federation of Red Cross and Red Crescent Societies on 19 September 1999 about 600,000 people, or almost three-quarters of the population of East Timor, had been displaced by the violence. According to the International Committee of the Red Cross another 200,000 were said to be refugees in (Indonesian) West Timor. (IHT 20-09-99)

In accordance with the UN decisions on the matter discussions started on the replacement of the multinational force by a UN peacekeeping force when Indonesia formally relinquished its claim to East Timor on 20 October 1999 and a period of UN interim administration set in. The questions to be dealt with were, particularly, who was to be part of it and who was to take command of it. (IHT 21-10-99)

The UN Security Council on 25 October 1999 voted unanimously under Chapter 7 of the UN Charter to set up the UN Transitional Administration in East Timor which would replace the international force (Res.1272). The UNTAET would comprise troops, military observers, police officers and civilian officials, and was given an initial mandate until 31 January 2001. On Chinese insistence the resolution made no direct mention of an inquiry set up by the UN High Commissioner for Human Rights. (IHT 26-10-99)

A proposal to put command of the UN force in the hands of Malaysia was rejected by the East Timorese leadership, who also objected to any other member of ASEAN for that post, and who preferred a continuation of an Australian commander. (IHT 03-11-99). In late December it was announced that a Philippine majorgeneral would command the UN force. (IHT 30-12-99) The transition to peacekeeping by the UN force would be completed by the end of February 2000. (IHT 03-02-00)

The idea of an inquiry into possible atrocities and human rights violations was later supported by the UN Commission on Human Rights which on 27 September 1999 called on the UN Secretary-General to establish a mechanism to "gather and compile systematically information on possible violations of human rights and acts which may constitute breaches of international humanitarian law committed in East Timor since the January 1999 announcement of the vote". Backed by many of its neighbours, Indonesia said it did not accept the resolution, as it had already decided earlier to set up a fact-finding body of its own on human rights violations in East Timor. The Asian members of the Commission voted against the resolution, except Japan which abstained. (IHT 28-09-99) Meanwhile, around mid-October, the UN Office for the Coordination of Humanitarian Assistance (OCHA) had stated there was no evidence to support allegations of occurrences of mass murder in East Timor. (IHT 14-10-99)

On the occasion of the visit by a UN-mandated five-member investigation team in December 1999 the Indonesian government rejected the idea of an international court in East Timor. The Indonesian foreign minister said: "Any effort whatsoever to pressure those that evidence suggests were involved in human rights abuses should 
also reflect the strategic importance of forming good relations and cooperation between Indonesia and East Timor in the future." (IHT 10-12-99)

It was reported in late January 2000 that the UN investigators would recommend the creation of an international tribunal. Meanwhile the Indonesian independent commission of inquiry had found that the Indonesian armed forces and the militias supported by them had been implicated in criminal actions in East Timor and had recommended that further investigation be conducted into the role of 20 to 30 persons, including some high-ranking and middle-ranking Indonesian military officers and civilians. The Indonesian government called on the UN to delay any move for an international tribunal until after Indonesia had had a chance to take its own action. A premature action by the UN could cause a nationalist backlash that would make it more difficult to bring military officers to justice. (IHT 31-01-00) During a visit to Indonesia and East Timor in February 2000 the UN Secretary-General stressed that it was up to Indonesia to punish those responsible for the violence and destruction in East Timor. He said there would be no need for an international court if Indonesia went through with its commitment to bring the offenders to justice. (IHT 18-02-00) [See for Indonesian legislation, supra at 236.]

The Indonesian president paid a brief visit to East Timor on 29 February 2000, where he apologized for the harsh 24-year Indonesian government. He laid a wreath on the site of a violent incident on 11 November 1991 and at a neighbouring Indonesian military cemetry. A communiqué was signed during the visit, calling, inter alia, for a corridor between East Timor and its coastal enclave of Ambeno. (IHT 01-03-00)

\section{SETTLEMENT OF DISPUTES}

See: Territorial claims and disputes

\section{SPECIAL TERRITORIES WITHIN A STATE: KASHMIR}

\section{Armed clashes and Pakistan-US agreement}

It was reported that separatist violence in the Indian state of Jammu and Kashmir had increased since India had begun its offensive against infiltrators in the Kargil area. (see 8 Asian YIL 308) The reason seemed to be that many troops earlier engaged in counter-insurgency operations had to be moved to Kargil. (IHT 01-07-99)

On 4 July 1999 Indian sources issued a report (denied by Pakistan) that Indian troops had recaptured a strategic mountain peak, just within the Indian side of the Line of Control.

Both India and Pakistan communicated with the US president on the issue and there was a flurry of signals that Pakistan might be willing to negotiate while insisting that they were not directly involved in the conflict. (IHT 05-07-99) The Pakistani prime minister flew to the US and an agreement was reached with the US president. 
A joint statement was issued, according to which Pakistan would withdraw its support for the armed groups who had occupied parts of Indian-held Kashmir since April 1999. The agreement also stated that concrete steps would be taken for the restoration of the 1972 Line of Control. The Pakistani chief of army staff accordingly said that the militants ("mujahidin") would be asked to "change their position". In exchange the US president pledged to take a "personal interest" in solving the Kashmir problem. The Pakistani prime minister defended his policy by arguing that it helped to usher the issue onto the world stage.

Although being the beneficiary of the agreement, the India through its foreign minister felt compelled, in view of its traditional attitude of not accepting "third-party mediation" in the Kashmir issue, to insist that the US role was no foreign mediation at all. (IHT 06, 07-07-99)

The Directors of military operations from both sides met and agreed to the terms and timetable for the pull-out of forces that Pakistan insisted were Islamic militants and that India maintained were mostly Pakistani soldiers or at least militants sponsored by the Pakistani military. Later, the Pakistani army chief acknowledged - for the first time - that Pakistani troops had indeed crossed the Line of Control into India during the fighting. (IHT 06-07, 07-07,13-07, 14-07, 17/18-07-99)

\section{Kashmir vote for autonomy}

The provincial assembly of the Indian state of Jammu and Kashmir approved a plan on 26 June 2000 to implement autonomy, against the wishes of the central government. The autonomy meant a return to the pre-1953 status when Kashmir had its own president and prime minister. In those first few years after the incorporation of Kashmir into India in 1947, all state activities except defence, foreign affairs and telecommunications were under local control. (IHT 27-06-00)

\section{STATE SUCCESSION}

\section{Timor Gap Treaty}

The Indonesian responsibilities and competences under the Indonesian-Australian "zone of cooperation" treaty ("Timor Gap Treaty") of 1989 were taken over by the United Nations upon the transfer of power over East Timor by Indonesia, pending the establishment of a state of East Timor.

The new state would have to determine its policy relating to the continuation or re-negotiation of the treaty as the successor state of Indonesia. It was reported that the East Timorese leadership was aiming at a seabed boundary halfway between the East Timorese shoreline and Australia, instead of the existing treaty arrangement, under which the zone in question was divided into three areas: area $\mathrm{C}$, at the northern end, administered by Indonesia (now: UN), area B, at the southern end, under Australian control, and a central area A, to be administered jointly. (IHT 14-12-99)

On 10 February 2000 the UN, on behalf of East Timor, and Australia signed a treaty (the "Timor Gap Oil and Gas Exploration Treaty") that continued the terms 
of the Indonesian-Australian treaty of 1989. It thus enabled an offshore oil and gas project for the tapping of the Bayu-Undan field to go ahead.

It was said that Indonesia had agreed that the zone included in the 1989 treaty was no longer within its jurisdiction. (IHT 12/13-02-00)

\section{TERRITORIAL CLAIMS AND DISPUTES}

\section{Malaysian occupation of Spratly reefs}

The Philippines and Vietnam protested at an alleged recent Malaysian occupation of several reefs in the Spratly Archipelago. It was said that Malaysia had built a radar tower, a two-storey building and a platform with a helicopter landing pad on one of the reefs called "Investigator Shoal". Defending the move, Malaysia said it sent scientists to two reefs that were on Malaysia's continental shelf as well as within its exclusive economic zone. (IHT 23-07-99)

\section{Code of conduct}

To try to preserve the peace, the Philippines had presented a draft regional code of conduct for the South China Sea, to be discussed in the annual ASEAN foreign ministers conference held in Singapore in July 1999. The draft was, however, referred to a working group which would not meet until October 1999. It was said that Malaysia had opposed the inclusion of an explanatory note in the code that called for China to join negotiations at an early stage to make the agreement final. (IHT 23-07-99) The Malaysian prime minister, however, on the eve of his visit to China in August, said that he would press the Chinese leadership to back the code. (IHT 13-08-99)

In November 1999 the Philippine foreign minister admitted that no agreement had been reached by ASEAN and Chinese officials on the code, and that negotiations on the code would be continued. (IHT 26-11-99) With regard to the same matter the Philippine president during the third "ASEAN+3" meeting in late November 1999 had spoken of the possibility of setting up an East Asia security forum to manage and resolve tensions in the region. (IHT 29-11-99) On the other hand, a Chinese spokesman said that if the dispute among Asian countries over the Spratly Islands could not be resolved, the countries involved should jointly develop the islands. (IHT 30-11-99)

\section{TERRORISM}

(See also: Organization of the Islamic Conference, supra at 410)

\section{UN Security Council on rendition of terrorism suspect}

The UN Security Council on 15 October 1999 voted to impose limited sanctions on the Taleban movement that ruled Afghanistan (Res.1267) to pressure it to turn over USAMA BIN LADEN "to appropriate authorities in a country where he has been indicted [such as the US], or to appropriate authorities in a country where he will 
be returned to such a country, or to appropriate authorities in a country where he will be arrested and effectively brought to justice" for masterminding the US embassy bombings in Kenya and Tanzania in 1998. The expulsion had to be carried on 14 November at the latest.The sanctions consisted of freezing the Taleban's overseas assets and banning Taleban-operated aircraft from taking off and landing outside Afghanistan. (IHT 16/17-10-99)

In late October the Taleban, through its representative in New York, offered to convene an international panel of Islamic scholars or Ulama, to judge USAMA BIN LADEN's fate. (IHT 01-11-99)

\section{US accusations}

The US in its latest annual report on US efforts to combat terrorism for the first time identified South Asia as a major hub of international terrorism, accusing Pakistan and Afghanistan of providing a haven and support for international terrorist groups.

Since 1993 the US had accused Cuba, Iran, Iraq, Libya, North Korea, Sudan, and Syria of harbouring and aiding ("sponsoring") "terrorists", but had stopped short of adding either Pakistan or Afghanistan to the list. This was explained, according to the US State Department, by the fact that the US did not recognize the current Afghanistan (Taleban) government and, in the case of Pakistan, because "it is a friendly state that is trying to tackle the problem".

Pakistan denied the US accusation. (IHT 02-05-00)

\section{WEAPONS}

\section{Use of nuclear weapons by India}

The government on 17 August 1999 publicized a proposal for a national nuclear doctrine, made by the National Security Advisory Board. The proposal read, inter alia, that "Any adversary must know that India can and will retaliate with sufficient nuclear weapons to inflict destruction and punishment if nuclear weapons are used against India and its forces. ... India will not be the first to initiate a nuclear strike ["no first use"], but will respond with punitive retaliation should deterrence fail". This was the government's first formal declaration on the subject. Up to then it had been said that nuclear weapons would be used as a "minimum credible deterrent" to nuclear war, but it had not been spelled out what that meant. (IHT 18-08-99) 